\title{
LIFE CYCLE ANALYSIS FOR THE TREATMENT OF ORGANIC MATTER FROM MUNICIPAL SOLID WASTE: A CASE STUDY OF FRANCE
}

\author{
LINA PINTO DIAZ ${ }^{1}$, PEGGY GUNKEL-GRILLON ${ }^{2} \&$ ESTELLE ROTH $^{1}$ \\ ${ }^{1}$ GSMA UMR CNRS 7331, University of Reims Champagne Ardennes, France \\ ${ }^{2}$ ISEA, University of New Caledonia, New Caledonia, Canada
}

\begin{abstract}
Organic valorisation of wastes by composting, anaerobic digestion or anaerobic digestion followed by composting is considered as one of the recycling solutions. In this study a life cycle inventory was performed for home composting in order to assess environmental impact of diverting organic household waste from landfill and incineration in the context of French waste management because it is known that composting can lead to greenhouse gases, volatile organic compounds and heavy metals emissions. A life cycle analysis was computed with various home composting, incineration and landfill rates. Results show that diverting $100 \%$ of organic household waste to composting decreases global warming potential, eutrophication potential and marine aquatic ecotoxicity potential of $19.1 \%, 38.6$ and $34.0 \%$, respectively. The benefits in global warming potential and eutrophication are mainly due to the replacement of mineral fertilizers by compost. But human toxicity potential, terrestric ecotoxicity potential and freshwater aquatic ecotoxicity potential significantly increase by more than $1000 \%$. This is mainly due to metal emission in agricultural soils during the compost use. However, the metal content of compost is still lower than the upper limit for compost label NF-44051.This study demonstrates for the first time that, under conditions assumed in life cycle analysis, home composting represents a reliable alternative to reduce environmental impacts of municipal waste produced in France.
\end{abstract}

Keywords: home composting, waste management, life cycle analysis, environmental impacts, organic household wastes.

\section{INTRODUCTION}

Economic and population growth, as well as modern consumerism lead to a huge increase of municipal waste production. The European directive 2008/98/CE established a hierarchy in the waste management as follow: prevention; preparing for re-use; recycling; other recovery, e.g. energy recovery and disposal. Regarding this directive, organic valorisation prevails in front of incineration with energy recovery and incineration is preferred to landfill. In accordance with this directive, France wants to reduce waste production and to divert waste from landfill and/or incineration. The European Union target is to divert $30 \mathrm{~kg}$ per inhabitant and per year ( $\mathrm{kg} / \mathrm{inh} a b / \mathrm{yr})$ in 2030. Several strategies about organic fraction of municipal solid waste management have been discussed in the literature. Organic material recycling via composting or anaerobic digestion appears to be the two alternatives for the organic fraction of municipal solid wastes. A life cycle analysis (LCA) assessment of incineration against anaerobic digestion before composting stated that anaerobic digestion reduced human and terrestrial toxicity versus incineration for a 52\% source segregated collection [1]. Anaerobic digestion is more beneficial for the environmental [2] but needs segregated collection of organic wastes, transportation and material. However, household composting, managed privately and performed beside the waste production is supported by the French environmental agency ADEME (Agence de l'Environnement de la Maîtrise de l'Energie) delivering home composters. It supresses collection step, fuel and greenhouse gases emissions [3]-[5], and commercial fertilizers may be replaced by compost for home gardening. However composting can generate environmental impacts. Composting generates 
gases such as methane, carbon dioxide, nitrous oxide, carbon monoxide and a variety of sulphur derived compounds such as methyl mercaptan, volatile organic compounds and the final product may contain heavy metals [6]-[9]. Environmental effects of home composting and environmental effect of diverting organic waste from landfill and incineration was then required. A LCA is needed to assess environmental impacts of the overall home composting operation. Emission factors of composting were derived from the literature and a comparative LCA of different disposal strategies was performed. Life cycle inventories for landfill, incineration and energy were specific for French processes.

\section{LIFE CYCLE ASSESSMENT}

\subsection{Methodology}

Standard ISO14040-14044 methodology of LCA with four steps (goal and scope definition; inventory analysis; impact assessment; interpretation) was used. The impact assessment method was CML 2001 [10]. This work provides an attributional LCA.

\subsection{Goal and functional unit}

The goal was to make a life cycle inventory for home composting and to assess environmental impact of diverting bio-waste from landfill and incineration toward home composting, in the context of French waste management (data, processes). Energy recovery and use of compost instead of mineral fertilizer were considered. Emission factors of composting were derived from the literature and LCA was performed with the software GABI 6 provided by PE international.

The functional unit was the amount of organic household waste produced per inhabitant and per year. The last national municipal residual waste characterization campaign in France was conducted in 2007 [11]. The amount of household solid waste produced in 2007 was $391 \mathrm{~kg} /$ inhab/yr including $81 \%$ of household residual waste $(316 \mathrm{~kg} / \mathrm{inhab} / \mathrm{yr})$. Only nonmeat based food and garden wastes (respectively $15.0 \%$ and $4.7 \%$ of household residual) i.e. $62.3 \mathrm{~kg} / \mathrm{inhab} / \mathrm{yr}$ are the organic fraction suitable for home composting [12]. This organic waste amount calculated for 2007 was assumed to be still valuable in 2017 since no significant changes occurred for organic waste management in France. Therefore the functional unit was $62.3 \mathrm{~kg} / \mathrm{inhab} / \mathrm{yr}$.

\subsection{System boundaries}

System expansion was considered. The conceptual model used was as in [13] and rests on the consideration of a waste management system or foreground system and a compensatory system as a background. Foreground system input was organic household waste generated in households and included three ways for waste disposal: home composting production, incineration and landfill (Fig. 1):

- Home composting production: input was organic household waste suitable for home composting and output was compost product.

- Compost use in private garden: took into account emissions to soil and air due to its use as a soil conditioner and fertilizer.

- Production and use of mineral fertilizers: credits for the production and the use of ammonium nitrate fertilizer and triple super phosphate fertilizer were included. 


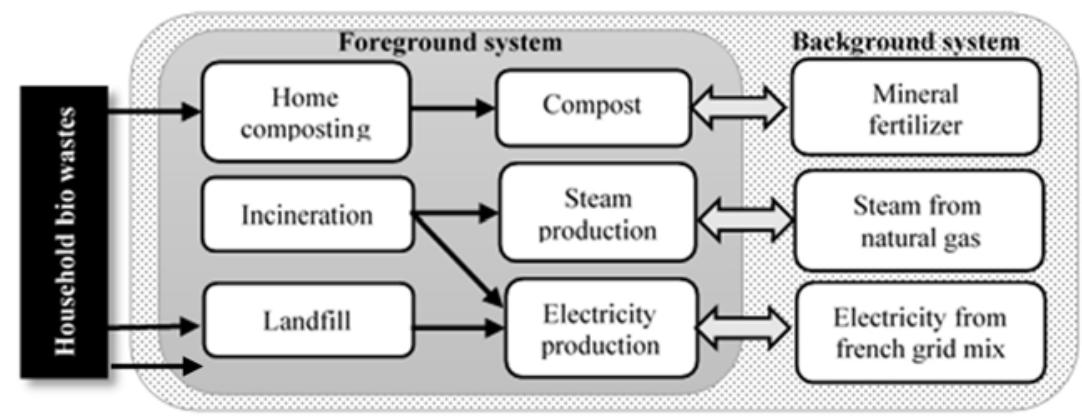

Figure 1: Methodology for LCA with system boundaries.

- Incineration of the biodegradable waste fraction of municipal solid waste considered a data set based in an average European waste to energy plant without collection, transport and pre-treatment (European Life Cycle Database).

- Landfill considered data of compactor operation, structure isolation materials and its respective manufacturing process, leachate and gas treatment, as well as final disposal of treated effluents (GABI database, PE International). No transport, collect and pretreatment was considered within system burdens.

Secondary outputs were materials and energy. The waste treatment and co-product production (energy: steam/electricity, compost, and recycled materials) were included in the waste foreground system boundaries. The background electricity process was the French electricity grid mix (GABI database). The steam production with natural gas production using a French technology was also provided by GABI database. Life cycle inventory for fertilizers production and use was provided by a literature survey and calculations. No waste transport to incineration or landfill was considered.

Home composting of organic household waste presents the great advantage to suppress waste transport to disposal but also to avoid the transport of mineral fertilizer since compost is used as fertilizer. The transport of organic household waste collected within the municipal residual waste wasn't taken into account in the system boundaries to avoid a huge variability of the distance. Nevertheless, to assess the influence of transport, additional computation was performed with transport for two scenarios. Transport of waste was simulated with a 20-26 t gross weight truck and a $17.3 \mathrm{t}$ payload capacity. Emission were average values from Euro 0-5 (GABI database). Fuel supply was from crude oil and bio components (GABI database). The annual distance travelled for transport was estimated to be $3,000 \mathrm{~km}$ for $50 \mathrm{~km}$ annual distance and 60 municipal solid waste collections per year.

\subsection{Scenarios}

Five scenarios have been computed. The reference one $\mathrm{SC}_{0-58-42}$ was without home composting but incineration and landfilling rates were respectively $58 \%$ and $42 \%$ according to [14]. The second scenario, $\mathrm{SC}_{33-33-33}$, was settled to compare the three waste disposal strategies, the third one, $\mathrm{SC}_{48-30-22}$, to follow the European Union 2030 target corresponding to $30 \mathrm{~kg} / \mathrm{inhab} / \mathrm{yr}$ of organic waste recycled. For the fourth one, $\mathrm{SC}_{48-52-0}$, landfill is replaced by incineration with energy valorisation. The fifth and last scenario, $\mathrm{SC}_{100-0-0}$, was a $100 \%$ home composting scenario. $\mathrm{SC}_{0-58-42}$ and $\mathrm{SC}_{100-0-0}$ were those also computed with transport of municipal wastes. 


\section{LIFE CYCLE INVENTORY}

\subsection{Emissions related to home compost production and use}

Data considered in life cycle inventory were selected through a literature survey (Table 1).

Substances considered for gaseous emissions related to compost production were carbon dioxide and oxide $\left(\mathrm{CO}_{2}\right.$ and $\left.\mathrm{CO}\right)$, methane $\left(\mathrm{CH}_{4}\right)$, ammonia $\left(\mathrm{NH}_{3}\right)$ and nitrous oxide $\left(\mathrm{N}_{2} \mathrm{O}\right)$. Data provides from field studies conducted with different composting techniques including windrow and home composting. Standard deviations were large especially for air emissions (effect of the variation of gaseous emissions on environmental impact will be tested in the sensitivity section).

Leachate production is variable: $28.37 \mathrm{~L} / \mathrm{t}_{\mathrm{ww}}$ to $130 \mathrm{~L} / \mathrm{t}_{\mathrm{ww}}$ [15], [20] and the mean leachate production considered for groundwater emissions of metal is then $79 \pm 72 \mathrm{~L} / \mathrm{t}_{\mathrm{ww}}$. The leachate composition was as mentioned in [20] and the high standard deviation is related to the large uncertainty on the leachate volume (effect of metal composition of the leachate will also be tested in the sensitivity section). The compost production rate was $0.36 \pm 0.12 \mathrm{t}_{\text {compost }} / \mathrm{t}_{\mathrm{ww}}$ [14], [20]. Phosphorus, nitrogen, potassium and heavy metals contents in compost are expressed in mass percentage per dry matter of compost [9], [20], [21], their values were corrected by dry weight of compost to get kg per ton of wet compost (Table 2).

The emission inventory of compost use [17] was performed considering that composted wastes were $76 \%$ kitchen wastes and $23 \%$ garden wastes [12]. Metal emissions in soil were calculated using the SALCA/Ecoinvent model and considering $\mathrm{Cd}, \mathrm{Cr}, \mathrm{Cu}, \mathrm{Hg}, \mathrm{Ni}, \mathrm{Pb}$ and $\mathrm{Zn}$ content estimated previously in compost. Metal input by atmospheric deposition and

Table 1: Emissions for: (a) compost production (per ton of wet organic waste $\left(\mathrm{t}_{\mathrm{ww}}\right)$ ); and (b) for compost use (per ton of compost ( $\left.t_{\text {compost }}\right)$ ).

\begin{tabular}{|c|c|c|c|c|c|c|c|}
\hline \multirow{2}{*}{\multicolumn{2}{|c|}{$\begin{array}{c}\text { (a) Compost production } \\
\text { Air emissions kg/t } \\
{[7],[15]-[19]}\end{array}$}} & \multicolumn{6}{|c|}{ (b) Compost use } \\
\hline & & \multicolumn{2}{|c|}{$\begin{array}{l}\text { Air emissions } \\
\text { kg/t } \text { tompost }\end{array}$} & \multicolumn{4}{|c|}{$\begin{array}{l}\text { Groundwater emissions } \\
\qquad \mathrm{g} / \mathrm{t}_{\text {compost }}\end{array}$} \\
\hline $\mathrm{CO}_{2}$ & $225 \pm 118$ & $\mathrm{CO}_{2}$ & 338 & $\mathrm{NO}_{3}^{-}$ & 12 & $\mathrm{Sb}$ & 0.07 \\
\hline $\mathrm{CH}_{4}$ & $3.08 \pm 1.89$ & $\mathrm{NH}_{3}$ & 0.01 & $\mathrm{~K}$ & 2300 & $\mathrm{Cd}$ & 0.00 \\
\hline $\mathrm{NH}_{3}$ & $0.52 \pm 0.42$ & $\mathrm{~N}_{2} \mathrm{O}$ & 0.3 & $\mathrm{Cl}^{-}$ & 1000 & $\mathrm{Hg}$ & 0.00048 \\
\hline $\mathrm{CO}$ & $0.09 \pm 0.06$ & \multirow{2}{*}{\multicolumn{2}{|c|}{$\begin{array}{l}\text { Soil emissions } \\
\mathrm{g} / \mathrm{t}_{\text {compost }}\end{array}$}} & $\mathrm{Ca}$ & 1100 & & \\
\hline $\mathrm{N}_{2} \mathrm{O}$ & $0.20 \pm 0.17$ & & & $\mathrm{Na}$ & 390 & & \\
\hline \multirow{2}{*}{\multicolumn{2}{|c|}{$\begin{array}{c}\text { Groundwater emissions } \mathbf{g} / \mathbf{t}_{\mathbf{w w}} \\
{[17],[20]}\end{array}$}} & $\mathrm{Al}$ & 9388 & $\mathrm{SO}_{4}{ }^{2-}$ & 770 & & \\
\hline & & $\mathrm{Zn}$ & 9060 & $\mathrm{Fe}$ & 170 & & \\
\hline $\mathrm{NO}_{3}^{-}$ & $13.14 \pm 1.19$ & Mn & 171.2 & $\mathrm{Al}$ & 29.6 & & \\
\hline $\mathrm{NH}_{4}^{+}$ & $3.72 \pm 0.33$ & As & 226.6 & $\mathrm{Fe}$ & 43.1 & & \\
\hline $\mathrm{K}$ & $508 \pm 39$ & $\mathrm{Cu}$ & 2.7 & $\mathrm{Zn}$ & 4.2 & & \\
\hline $\mathrm{P}$ & $6.1 \pm 1.0$ & $\mathrm{~Pb}$ & 57.2 & $\mathrm{Mn}$ & 2.6 & & \\
\hline $\mathrm{Cu}$ & $0.023 \pm 0.004$ & $\mathrm{Ni}$ & 15.8 & As & 0.43 & & \\
\hline $\mathrm{Cd}$ & $0.0002 \pm 0.0000$ & Mo & 6.1 & $\mathrm{Cu}$ & 0.45 & & \\
\hline $\mathrm{Cr}$ & $0.0025 \pm 0.0004$ & $\mathrm{Cr}$ & 1.8 & $\mathrm{~Pb}$ & 0.17 & & \\
\hline $\mathrm{Ni}$ & $0.0069 \pm 0.0011$ & $\mathrm{Sb}$ & 11.3 & $\mathrm{Ni}$ & 0.21 & & \\
\hline $\mathrm{Pb}$ & $0.0079 \pm 0.0012$ & $\mathrm{Cd}$ & 0.3 & Mo & 0.42 & & \\
\hline As & $0.0019 \pm 0.0004$ & $\mathrm{Hg}$ & 0.2 & $\mathrm{Cr}$ & 0.04 & & \\
\hline $\mathrm{Zn}$ & $0.033 \pm 0.004$ & & & & & & \\
\hline
\end{tabular}


Table 2: NFU 44-051 recommended values and compost composition per ton of compost.

\begin{tabular}{|ccc|ccc|}
\hline & NFU44-051 & Content kg/t compost & & NFU44-051 & Content g/t compost \\
\hline NTK & - & $10.3 \pm 2.7$ & $\mathrm{Cr}$ & 120 & $11 \pm 3$ \\
$\mathrm{P}$ & $<8.4$ & $2.7 \pm 0.6$ & $\mathrm{Cu}$ & 300 & $21 \pm 2$ \\
$\mathrm{~K}$ & $<19.5$ & $7.2 \pm 1.5$ & $\mathrm{Ni}$ & 60 & $5.1 \pm 2.4$ \\
$\mathrm{OM}$ & $>200$ & $188.6 \pm 63.5$ & $\mathrm{Cd}$ & 3 & $0.12 \pm 0.01$ \\
& & & $\mathrm{Zn}$ & 600 & $88 \pm 11$ \\
& & & $\mathrm{Hg}$ & 2 & $0.04 \pm 0.02$ \\
& & & $\mathrm{~Pb}$ & 180 & $8.6 \pm 2.3$ \\
\hline
\end{tabular}

metal output by lixiviation and soil erosion were calculated according to study [22] and the influence of culture on the metal balance was established for potatoes crop with metal content of seed and potatoes [22].

\subsection{Emissions related to fertilizers production and use}

Considering fertilizing properties of compost, system was credited for nitrogen and phosphate contents and it was assumed that $\mathrm{N}$ and $\mathrm{P}$ provided by compost could replace mineral fertilizers such as ammonium nitrate and triple super phosphate. For fertilizers production, values of main impact categories were from [23] (Table 3).

Table 3: Energy consumption, global warming potential (GWP), eutrophication potential (EP), acidification potential (AP) and abiotic resource use due to mineral fertilizers production and emissions related their use.

\begin{tabular}{|c|c|c|}
\hline & $\begin{array}{c}\text { Ammonium } \\
\text { nitrate }\end{array}$ & $\begin{array}{c}\text { Triple super } \\
\text { phosphate }\end{array}$ \\
\hline \multicolumn{3}{|c|}{ Emissions related to fertilizers production/kg fertilizer } \\
\hline Energy consumption (MJ) & 40 & 30 \\
\hline GWP $\left(\mathrm{kg} \mathrm{CO}_{2}\right.$ eq. $)$ & 6.2 & 1.7 \\
\hline $\mathrm{EP}\left(\mathrm{g} \mathrm{PO}_{4}{ }^{3-}\right.$ eq. $)$ & 0.5 & 0.7 \\
\hline $\mathrm{AP}\left(\mathrm{g} \mathrm{SO}_{2}\right.$ eq. $)$ & 4.7 & 8.1 \\
\hline Abiotic resource use (g Sb eq.) & 23 & 15 \\
\hline \multicolumn{3}{|c|}{ Air emissions related to fertilizers use $\mathrm{g} / \mathrm{kg}$ fertilizer } \\
\hline $\mathrm{NH}_{3}$ & 20 & - \\
\hline $\mathrm{N}_{2} \mathrm{O}$ & 17 & - \\
\hline $\mathrm{NO}_{\mathrm{x}}$ & 3.5 & - \\
\hline \multicolumn{3}{|c|}{ Groundwater emissions related to fertilizers use $\mathrm{g} / \mathrm{kg}$ fertilizer } \\
\hline $\mathrm{NO}_{3}^{-}$ & 347 & - \\
\hline $\mathrm{PO}_{4}^{3-}$ & - & 1.3 \\
\hline \multicolumn{3}{|c|}{ Soil emissions related to fertilizers use $\mathrm{mg} / \mathrm{kg}$ fertilizer } \\
\hline $\mathrm{Pb}$ & 1.6 & 20 \\
\hline $\mathrm{Cd}$ & 0.08 & 95 \\
\hline $\mathrm{Ni}$ & 0.05 & 10 \\
\hline $\mathrm{Cr}$ & 0.54 & 927 \\
\hline $\mathrm{Zn}$ & 2.8 & 1,794 \\
\hline $\mathrm{Cu}$ & 1.0 & 158 \\
\hline $\mathrm{Hg}$ & 0.02 & 1.55 \\
\hline
\end{tabular}


$\mathrm{NH}_{3}, \mathrm{~N}_{2} \mathrm{O}, \mathrm{NO}_{\mathrm{X}}$ and $\mathrm{NO}_{3}^{-}$emissions related to mineral fertilizers application were calculated using the Ecoinvent ${ }^{\mathbb{R}}$ average model [24]. Metallic trace elements emissions were determined using the SALCA/Ecoinvent ${ }^{\circledR}$ model [25]. $\mathrm{PO}_{4}{ }^{3-}$ leaching to groundwater was calculated according to the model SALCA-P/Ecoinvent ${ }^{\mathbb{R}}$ [26]. Emissions expressed in $\mathrm{kg} / \mathrm{m}^{2} / \mathrm{yr}$ in these models were converted into $\mathrm{g}$ or $\mathrm{mg}$ per $\mathrm{kg}$ of fertilizer using a fertilizer application rate of $0.088 \mathrm{~kg} / \mathrm{m}^{2} / \mathrm{yr}$ for ammonium nitrate and $0.038 \mathrm{~kg} / \mathrm{m}^{2} / \mathrm{yr}$ for triple super phosphate. These application rates correspond to the $\mathrm{N}$ or P content in $3 \mathrm{~kg} / \mathrm{m}^{2} / \mathrm{yr}$ of compost, which is the standard compost application rate.

\subsection{Waste-to-energy of biodegradable waste fraction in municipal solid waste}

Waste to energy referred to the process of turning municipal solid waste into a source of heat and then into electrical energy. Waste to energy of the biodegradable waste fraction considered a data set based on European waste to energy plant from European reference Life Cycle Database. System didn't take into account collection, transport and pre-treatment but boundaries included emissions treatment and disposal of solid residues (such as bottom ash) in landfills or in salt mines. System considered credits for metal scraps; recovered from bottom ash. Organic fraction of municipal solid waste was not supposed to contain metals but it was assumed that organic waste is mixed with other wastes before incineration to ensure emission compliance and a relatively constant calorific value. Credits from French electricity grid mix and process steam production from natural gas were considered within the burdens. Average energy recovery for incineration was equal to $0.495 \mathrm{GJ}$ of electricity per ton of biodegradable municipal solid waste and 1.28 GJ per ton of biodegradable municipal solid waste of process steam.

\subsection{Landfill of biodegradable}

Life cycle inventory for landfill was provided by PE International and issued from French data. It included gas use and leachate treatment but it didn't include biodegradable waste collection, transport and pre-treatment steps. The electricity production was 369 MJ per ton of household wastes. Distribution of landfill gas was $22 \%$ flare, $28 \%$ used and $50 \%$ emissions.

\subsection{Energy recovery credits}

Electricity and thermal energy were credited using French electricity grid mix $(76.4 \%$ nuclear, $11.9 \%$ hydro, $4.1 \%$ hard coal, 3.8\% natural gas) and an average of French process of steam generation from natural gas, respectively (PE International database).

\section{RESULTS AND DISCUSSION}

\subsection{Contribution of home composting, incineration and landfill on impact categories}

Scenario $\mathrm{SC}_{33-33-33}$ with equal disposal of bio-waste between composting, incineration and landfill enables to determine that composting contributes at $20 \%$ to GWP, at $38 \%$ to AP, at $94 \%$ to human toxicity potential (HTP), at $96 \%$ to terrestric ecotoxicity potential (TETP) and at $100 \%$ to freshwater aquatic ecotoxicity (FAETP) (Fig. 2). Incineration contributes at $29 \%$ to GWP, at $34 \%$ to AP and at $80 \%$ to marine aquatic ecotoxicity potential (MAETP). Landfill contributes at $50 \%$ to GWP (the model considers that $50 \%$ of gas produced are emitted to the atmosphere), at $96 \%$ to EP and at $29 \%$ to AP. 


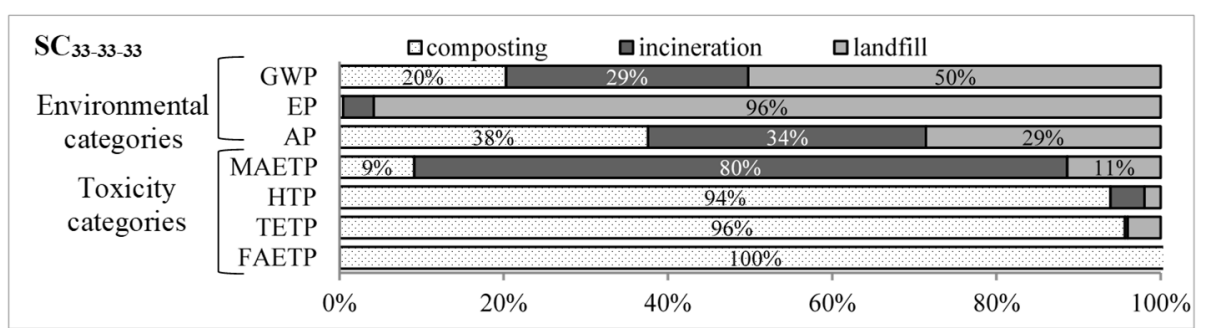

Figure 2: Incineration, landfill and home composting contribution to GWP, EP, AP, MAETP, HTP, TETP, FAETP (including related credits).

Considering that home composting has a low or nil contribution to GWP, EP and MAETP, an increase of home composting rate will reduce these impact categories. But TETP and HTP will drastically increase and it is due to heavy metal contents in compost and their potential transfer to soil. Nevertheless, the mean metal contents in compost (Table 2) are 5 to 10 times lower than the NFU-44-051 upper limit values for normalized compost agreement and heavy metals contents measured in home compost were within legal requirements [9], [21].

\subsection{Influence of home composting rates on impact categories}

GWP is the major environmental category with $24-45 \mathrm{~kg} \mathrm{CO}_{2}$-eq./inhab/yr while MAETP is the major toxicity category with $2.9 \times 10^{2}$ to $1.6 \times 10^{3} \mathrm{~kg}$ DCB-eq./inhab/yr (Table 4). POCP and OLDP are minor impacts and will not be discussed further in the study.

As expected, GWP, EP and MAETP highly decrease with compost rate. But AP and especially HTP and TETP increase with compost rate increase. Home composting penalizes strongly these two latest toxicity categories. With the $100 \%$ composting scenario, $\mathrm{SC}_{100-0-0}$, results, in accordance with a LCA of industrial versus home composting [27] demonstrate that AP increases slightly in comparison with the first scenario but GWP, EP and MAETP can be drastically reduced.

Table 4: Influence of home composting rates on emissions (/inhab./yr): GWP, EP, AP, photochemical ozone creation potential (POCP), ozone layer depletion potential (OLDP), MAETP, HTP, TETP and FAETP.

\begin{tabular}{|c|c|c|c|c|}
\hline & $\mathrm{SC}_{0-58-42}$ & $\mathrm{SC}_{48-30-22}$ & $\mathrm{SC}_{48-52-0}$ & $\mathrm{SC}_{100-0-0}$ \\
\hline Environmental categories & & & & \\
\hline GWP (kg CO 2 -eq.) 100 years & 45 & 35 & 29 & 24 \\
\hline $\mathrm{EP}\left(\mathrm{kg} \mathrm{PO}{ }^{3-}\right.$ eq. $)$ & $4.910^{-2}$ & $2.610^{-2}$ & $2.510^{-2}$ & $5.310^{-4}$ \\
\hline $\mathrm{AP}$ (kg SO${ }_{2}$-eq.) & $1.810^{-2}$ & $2.010^{-2}$ & $2.010^{-2}$ & $2.210^{-2}$ \\
\hline POCP (kg Ethene-eq.) & $6.610^{-3}$ & $3.910^{-3}$ & $6.010^{-4}$ & $8.110^{-4}$ \\
\hline OLDP (kg R11-eq.) & $-1.110^{-6}$ & $-1.210^{-6}$ & $-1.310^{-6}$ & $-1.310^{-6}$ \\
\hline Toxicity categories & & & & \\
\hline MAETP (kg DCB-eq.) & $1.610^{3}$ & $9.910^{2}$ & $1.510^{3}$ & $2.910^{2}$ \\
\hline HTP (kg DCB-eq.) & $1.510^{-1}$ & 2.1 & 2.1 & 4.3 \\
\hline TETP (kg DCB-eq.) & $2.410^{-2}$ & 0.60 & 0.59 & 1.2 \\
\hline FAETP (kg DCB-eq.) & $-8.510^{-3}$ & 0.56 & 0.55 & 1.2 \\
\hline
\end{tabular}




\subsection{Influence of credits on GWP and on EP}

For GWP, composting is the most sensitive to credits (Fig. 3(a)). Here, electricity credits do not influence significantly GWP of waste disposal treatments because the system was credited with French Mix, which is low carbon-electricity. Indeed, comparison of municipal solid waste incineration in different countries (Germany, Italy, UK and France) revealed lower credits and consequently higher overall footprint for system credited with French grid mix because of mostly nuclear electricity source [28]. The GWP reduction with credits is mainly due to credits related to the replacement of mineral fertilizers by compost.

For EP, composting is also the most sensitive to credits (Fig. 3(b)). Credits due to the lack of mineral fertilizers production and use significantly contribute to the EP reduction when composting rate increases.

\subsection{Influence of landfill on environmental impacts}

Landfill of organic waste should be avoided (European Directive 1999/31/CE) since it is a worthier waste disposal than incineration [29]. The influence of landfill is highlighted comparing $\mathrm{SC}_{48-30-22}$ and $\mathrm{SC}_{48-52-0}$ (Table 4). Without landfill $\left(\mathrm{SC}_{48-52-0}\right)$, $\mathrm{GWP}$ is $29 \mathrm{~kg} \mathrm{CO}$-eq. for 100 years instead of 35. Landfill contributing at $50 \%$ of GWP for $\mathrm{SC}_{33-33-33}$ (Fig. 2), therefore a reduction of landfill rate decreases emissions related to GWP. AP is constant $\left(2.0 \times 10^{-2} \mathrm{~kg} \mathrm{SO}\right.$-eq. $)$ and $\mathrm{EP}$ has an impact slightly lower with $2.5 \times 10^{-2} \mathrm{~kg} \mathrm{PO}_{4}{ }^{3-}$-eq. Landfill contributing at $95 \%$ to $\mathrm{EP}$ (Fig. 2), replacing landfill by home composting decreases emissions related to EP.

\subsection{Home composting and energy saving}

With the reference scenario $\mathrm{SC}_{0-58-42}, 73.2 \mathrm{MJ} /$ inhab/yr can be saved, mainly due to energy production by incineration $(66.2 \mathrm{MJ} / \mathrm{inhab} / \mathrm{yr}$ produced by incineration plus 9.0 by landfill). Incineration is then the best strategy for energy production and thus saving. With scenario $\mathrm{SC}_{48-30-22}$ and $\mathrm{SC}_{100-0-0}$, compost production is respectively 10.8 and $22.5 \mathrm{~kg} / \mathrm{inhab} / \mathrm{yr}$ and only 52.4 and $30.8 \mathrm{MJ} / \mathrm{inhab} / \mathrm{yr}$ can respectively be saved. With home composting, energy can be saved from fertilizer production but this result illustrates that energy savings from mineral fertilizers production is lower than savings for incineration but still, home composting allows energy saving.

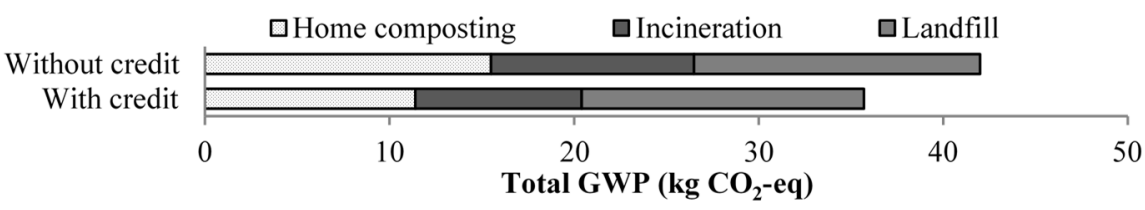

(a)

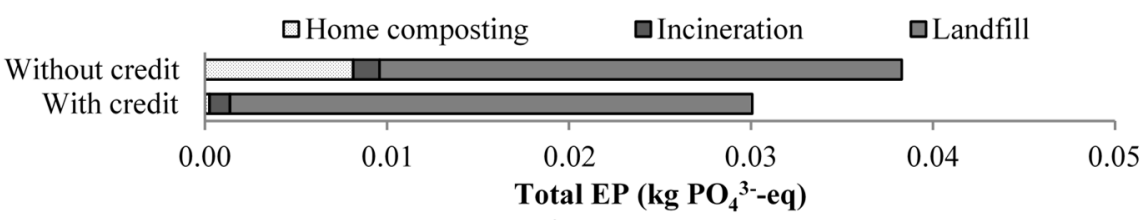

(b)

Figure 3: Influence of credits: (a) on GWP; and (b) on EP. 
4.6 Sensitivity analysis on the 2030 target scenario $\mathrm{SC}_{48-30-22}$

\subsubsection{Influence of greenhouse gas emissions on GWP}

Considering highest gas emissions values related to compost production (mean plus standard deviation: $225+118 \mathrm{~kg} / \mathrm{t}_{\mathrm{ww}}$ for $\mathrm{CO}_{2}, 3.08+1.9 \mathrm{~kg} / \mathrm{t}_{\mathrm{ww}}$ for $\mathrm{CH}_{4}$ and $0.20+0.7 \mathrm{~kg} / \mathrm{t}_{\mathrm{ww}}$ for $\mathrm{N}_{2} \mathrm{O}$ (Table 1), the GWP increases significantly from 35 to $42 \mathrm{~kg} \mathrm{CO}_{2}$-eq. for 100 years but it is still below the reference scenario $\mathrm{SC}_{0-58-42}$ (Table 4). Considering $50 \%$ rise of gas emissions related to compost use $\left(338+50 \%=507 \mathrm{~kg} \mathrm{CO} / \mathrm{t}_{\text {compost }}\right.$ and $0.30+50 \%=0.45 \mathrm{~kg}$ $\mathrm{N}_{2} \mathrm{O} / \mathrm{t}_{\text {compost }}$ ) (Table 1), the GWP reaches $43.0 \mathrm{~kg} \mathrm{CO}$-eq. for 100 years but it is still below the reference scenario $\mathrm{SC}_{0-58-42}$ (Table 4). Nevertheless, these results highlight that composting must be aerated, brewed and the humidity must be checked in order to limit anaerobic phenomenon and then greenhouse gas emissions.

\subsubsection{Influence of metal emissions on impacts}

Considering high metal emission values (100\% rise) related to compost production, MAETP and FAETP are not significantly affected $(<0.3 \%)$. Considering high metal emissions to agricultural soils (100\% rise) related to compost use, the MAETP, HTP, FAETP and TETP increase. These categories are predominantly affected by composting (Fig. 2) explaining their high sensitivity to metal emissions to agricultural soils. Metal emissions appear to be the main negative effect of home composting on impacts.

\subsubsection{Influence of transport on impact categories}

Relative emissions between the 2030 target scenario $\mathrm{SC}_{0-58-42}$ and the reference one $\mathrm{SC}_{48-30-22}$ computed with or without transport illustrate that benefits related to home composting are slightly enhanced by transport awareness for GWP and MAETP (Table 5). A previous study [1] showed that the impact due to the transport was negligible when studying incineration versus organic valorisation by anaerobic digestion. But taking into account transport, relative AP is diminished $(+10 \%$ to $-33 \%$ with transport). Relative HTP and TETP is still positive when considering transport. But when transport is taken into account, the increase of these two emissions by home composting introduction is less important $(+1433 \%$ to $+438 \%$ for HTP and $+2054 \%$ to $+501 \%$ for TETP).

Thus, including transport in the computation reduces home composting negative effects on HTP and TETP.

Table 5: Effect of transport on relative GWP, EP, AP, MAETP, HTP and TETP for the target scenario $\mathrm{SC}_{48-30-20}$ and the reference one $\mathrm{SC}_{0-58-42}$.

\begin{tabular}{|c|c|c|}
\hline & $\begin{array}{l}\text { (SC48-30-2 } \\
\text { without } \\
\text { transport }\end{array}$ & $\begin{array}{l}\text { (0-58-42) } \times 100 \\
\text { with transport }\end{array}$ \\
\hline GWP 100 years (kg CO -eq.) & $-25 \%$ & $-30 \%$ \\
\hline $\mathrm{EP}\left(\mathrm{kg} \mathrm{PO}{ }^{3-}\right.$-eq. $)$ & $-56 \%$ & $-54 \%$ \\
\hline $\mathrm{AP}$ (kg SO 2 -eq.) & $+10 \%$ & $-33 \%$ \\
\hline MAETP (kg DCB-eq.) & $-32 \%$ & $-34 \%$ \\
\hline HTP (kg DCB-eq.) & $+1433 \%$ & $+438 \%$ \\
\hline TETP (kg DCB-eq.) & $+2054 \%$ & $+501 \%$ \\
\hline
\end{tabular}




\section{CONCLUSIONS}

Increase of home composting rate reduced impacts from environmental categories i.e. GWP, EP and MAETP. But this study also highlighted that an increase of home composting rate increased two toxicity impact categories: HTP and TETP. It is due to the increase of heavy metal emissions to soil for compost use. Nevertheless, regarding the life cycle inventory, the metal content in compost was 5 to 10 times lower than the upper limit fixed by NF-44-051 for compost normalization.

Home composting has the great advantage to be performed close of the site of wastes production and thus to avoid the transportation to plants for wastes treatment. $\mathrm{CO}_{2}$ emissions due to transportation are thus considerably reduced. Then considering transport in the system boundaries, the reduction of GWP by home composting is emphasized. Moreover the negative effects of home composting on HTP and on TETP are restricted. This result is in accordance with the principle of proximity for waste treatment as urged in the European Directive 2008/98/CE.

Replacing fertilizers by compost has a clear positive impact on environmental categories as EP and GWP. This result point out that a successful strategy of home composting should be accompanied by a marketing strategy to moderate mineral fertilizers use.

In France, diverting organic household waste from incineration and landfill is overall positive and mainly due to GWP, EP and MAETP decrease. Avoiding landfill by combining incineration and home composting or considering $100 \%$ composting appears to be a very good strategy regarding environmental impacts.

\section{REFERENCES}

[1] Di Maria, F. \& Micale, C., Life cycle analysis of incineration compared to anaerobic digestion followed by composting for managing organic waste: The influence of system components for an Italian district. Int. J. Life Cycle Assess., 20, pp. 377-388, 2015.

[2] Antonopoulos, L.S., Karagiannidis, A., Tsatsarelis, T. \& Perkoulidis, G., Applying waste management scenarios in the Peoloponnese region in Greece: A critical analysis in the frame of life cycle assessment. Environ. Sci. Pollut. Res., 20, pp. 2499-2511, 2013.

[3] De Oliveiera Simonetto, E. \& Borenstein, D., A decision support system for the operational planning of solid waste collection. Waste Management, 27, pp. 1286-1297, 2007.

[4] Di Maria, F. \& Micale, C., Impact of source segregation intensity of solid waste on fuel consumption and collection costs. Waste Management, 33, pp. 2170-2176, 2013.

[5] Iriarte, A., Gabarrell, X. \& Rieradevall, J., LCA of selective waste collection system in dense urban areas. Waste Management, 29, pp. 903-914, 2009.

[6] Brown, S., Kruger, C. \& Subler, S., Greenhouse gas balance for composting operations. J. Environ. Qual., 37(4), pp. 1396-1410, 2002.

[7] Andersen, J.K., Boldrin, A., Samuelsson, J., Christensen, T.H. \& Scheutz, C., Quantification of greenhouse gas emissions from windrow composting of garden waste. J. Environ. Qual., 39, pp. 713-724, 2009.

[8] Dorado, A.D., Husni, S., Pascual, G., Puigdellivol, C. \& Gabriel, D., Inventory and treatment of compost maturation emissions in a municipal solid waste treatment facility. Waste Management, 34(2), pp. 344-351, 2014.

[9] Smith, S.R. \& Jasim, S., Small-scale home composting of biodegradable household waste: Overview of key results from a 3-year research programme in West London. 
Waste Manage. \& Res.: The Journal of the International Solid Wastes and Public Cleansing Association, ISWA, 27(10), pp. 941-950, 2009.

[10] Guinée, J.B. et al., Handbook on Life Cycle Assessment. Operational Guide to the ISO Standards. I: LCA in Perspective. IIa: Guide. IIb: Operational Annex. III: Scientific Background, Kluwer Academic Publishers: Dordrecht, 692 pp., 2002.

[11] ADEME, Campagne Nationale de caractérisation d'ordures ménagères. Résultats année 2007, 2009.

[12] SCORVAL, Plan de Prévention et de Gestion des Déchets Non Dangereux Mission $\mathrm{n}^{\circ} 2$ : Réalisation d'une campagne de caractérisation des ordures ménagères et des encombrants rapport final, 2012.

[13] Miliute, J. \& Staniskis, J.K., Application of life-cycle assessment in optimisation of mmunicipal waste management systems: The case of Lithuania. Waste Manag. Reas. 28, pp. 298-308, 2010.

[14] ADEME, Plan départemental de prevention des dechets, guide du compostage, 2014.

[15] Amlinger, F., Peyr, S. \& Cuhls, C., Greenhouse gas emissions from composting and mechanical biological treatment. Waste Manag. and Reas., 26(1), pp. 47-60, 2008.

[16] Andersen, J.K., Boldrin, A., Christensen, T.H. \& Scheutz, C., Greenhouse gas emissions from home composting of organic household waste. Waste Management, 30(12), pp. 2475-2482, 2010.

[17] Boldrin, A., Hartling, K.R., Laugen, M. \& Christensen, T.H., Environmental inventory modelling of the use of compost and peat in growth media preparation. Resour. Conserv. Recy., 54, pp. 1250-1260, 2010.

[18] Hellebrand, H., Emission of nitrous oxide and other trace gases during composting of grass and green waste. J. Agr. Eng. Res., pp. 365-375, 1998.

[19] Quirós, R., Villalba, G., Muñoz, P., Font, X. \& Gabarrell, X., Environmental and agronomical assessment of three fertilization treatments applied in horticultural open field crops. J. Clean. Prod., 67, pp. 147-158, 2014.

[20] Andersen, J.K., Boldrin, A., Christensen, T.H. \& Scheutz, C., Mass balances and life cycle inventory of home composting of organic waste. Waste Management, 31(9-10), pp. 1934-1942, 2011.

[21] Barrena, R., Font, X., Gabarrell, X. \& Sánchez, A., Home composting versus industrial composting: Influence of composting system on compost quality with focus on compost stability. Waste Management, 34, pp. 1109-1116, 2014.

[22] Kotch, P. \& Salou, T., AGRIBALYSE - Rapport méthodologique, version 1.1, ADEME, 2014.

[23] Brentrup, F. \& Palliere, C., GHG emissions and energy efficiency in European nitrogen fertiliser production and use. Proceedings of the International Fertiliser Society, York, UK, Dec. 2008.

[24] Nemecek, T. \& Schnetzer, J., Methods of assessment of direct field emissions for LCIs of agricultural production systems. Agroscope Reckenholz, Tänikon Research Station ART: Zürich and Dübendorf, 2011.

[25] SOGREAH, Bilan des flux de contaminants entrants sur les sols agricoles de France métropolitaine, ADEME: Angers, France, p. 330, 2007.

[26] Nemecek, T. \& Kägi, T., Life Cycle Inventories of Swiss and European Agricultural Production Systems - Data v2.0. ecoinvent ${ }^{\circledR}$ report No. 15a. Ed Swiss Center for Life Cycle Inventories, Zurich and Dübendorf: Switzerland, p. 360, 2007.

[27] Martínez-Blanco, J. et al., The use of life cycle assessment for the comparison of biowaste composting at home and full scale. Waste Management, 30(6), pp. 983-994, 2010. 
80 Environmental Impact IV

[28] Jeswani, H.K., Smith, R.W. \& Azapagic, A., Energy from waste: carbon footprint of incineration and landfill biogas in the UK. Int. J. Life Cycle Assess., 18(1), pp. 218229, 2013.

[29] Cherubini, F., Bargigli, S. \& Ulgiati, S., Life cycle assessment (LCA) of waste management strategies: Landfilling, sorting plant and incineration. Energy, 34(12), pp. 2116-2123, 2009. 